\section{Karvatskii A., \\ Leleka 5. \\ Pedchenko A., \\ Lasariev T.}

\title{
INVESTIGATION OF THE CURRENT STATE OF ISOSTATIC GRAPHITE PRODUCTION TECHNOLOGY
}

Проаналізовано основні етапи сучасної технологї̈ виробництва високодисперсного ізостатичного графіту. Встановлено особливості та можливі напрямки ї удосконалення на підприємствах України. Розглянуто основні фактори, що визначають попит на ізостатичний графітовий матеріал. Спрогнозовано подальше зростання більш ніж на 5 \% щорічного обсягу виробництва ізостатичного графіту на світовому ринку, особливо в країнах Східної Азії.

Ключові слова: ізостатичний графіт, ізостатичне пресування, фотогальванічна промисловість, термостійкий матеріал, коксопекова композиція.

\section{Introduction}

Graphite materials are widely used in various industry fields due to unique combination of mechanical, chemical, thermal and physical properties. The material is used in metallurgy, energetics, engineering, on military-industrial complexes, during the manufacturing of fire-resistant materials, electrical machines and facilities, paint, rechargeable batteries, heaters etc.

Both natural and artificial graphite materials are used in industry. Artificial graphite is remarkable by its high clearness and is divided into various types based on its manufacturing method, the sphere of usage and application conditions. Isostatic graphite is a separate unique type of graphite materials which differs from other types of artificial graphite with better physical properties and its isotropy in the whole structure. The composites made from this material are similar to steel by its strength parameters. But it also possesses high electrical and thermal conductivity. Some industries practically cannot operate without graphite. For instance, electrodes from isostatic graphite in electrical discharge machines make it possible to achieve a significant increase in the accuracy of metal processing [1].

Isostatic graphite is a fine grain graphite which is obtained during the high pressure by the method of isostatic pressing. This material is used for product manufacturing of complex shapes with a high surface finish. Due to the needs of steel industry, isostatic graphite is used for making permanent molds, melting crucibles, continuous cast dye, hoppers, chutes etc. [2]. In the electrical field this material is used for elements of electronic tubes, containers for semiconductor, nets for rectifiers with mercury anodes. Isostatic graphite is an essential structural material for nuclear power reactors, solar photovoltaic cells etc.

The development of isostatic graphite production technology is conducted by leading manufacturers on the market of artificial graphite production since the 60-s of the last century. In the CIS countries and, particularly, in Ukraine domestic manufacturers became interested in this promising area after 2006, that is in the period of the rapid growth of the global photovoltaic industry. Such rapid development led to a lack of prospective graphite materials in the world market for the artificial graphite production [3]. Since that time the leading manufacturers have become engaged in the continuous expansion of isostatic graphite range and improving the technology of its production.

Under these circumstances, research and improvement of isostatic graphite production technology is clearly an urgent task.

\section{The object of research and its technological audit}

The object of research is the process of isostatic graphite production and the prospects for its further development in the world.

Nowadays isostatic graphite is quite popular material that is in great demand in the photovoltaic industry and is indispensable in semiconductors production. This can be explained by the unique properties of this type of graphite, which is characterized by high values of strength, heat resistance, electrical conductivity and uniformity of physical properties.

However, isostatic graphite production requires careful raw materials preparation, the usage of powerful specialized pressing equipment, the usage of accurately designed heat treatment modes etc. Ultimately, this leads to high prices of finished isostatic graphite in comparison to other types of graphite materials.

\section{The aim and objectives of research}

The objective is to study the process of gradual production of isostatic graphite material and determine the level of demand for products with fine-dispersed material on the world market.

To achieve the stated objective, the following tasks should be performed:

1. Identifying the main stages of isostatic graphite production and holding its detailed analysis.

2. Expanding overseas production technology features of isostatic graphite and identifying the opportunities for its improvement in Ukraine.

3. Setting the level for further development of world production of isostatic graphite materials and other materials based on it. 


\section{Research of existing solutions of the problem}

As a result of analysis of published data, it was found out that isostatic artificial graphite is obtained during several stages, namely [4-11]:

- pitch preparation and coke milling;

- coke and pitch mixing while heating the mixture;

- forming, cooling and chopping formed coke and pitch composition;

- pressing the crushed powder into billets under high pressure in special isostatic presses;

- firing blanks prepared at the temperature of 800 $1300^{\circ} \mathrm{C}$;

- burned carbon products graphitization at the temperatures up to $3000{ }^{\circ} \mathrm{C}$;

- graphite blanks processing to obtain the final product.

It was also established that the isostatic graphite is rather popular in photovoltaic industry in solar cells production which undergoes rapid development since 2006 [3, 12, 13]. This developing trend requires the usage of the new highpurity isotropic graphite brands and, therefore, new production technologies.

Thus, the results of analysis enable to conclude that the detailed description of isostatic graphite technology is protected by the leading foreign manufacturers producing graphite products. Therefore, research and records of the available information necessary for the development of the production area of new and promising structural graphite and products based on it can be considered as an extremely urgent task.

\section{Methods of research}

Methods of synthesis, analysis and systematization of the information available in the public domain and associated with the production of products using isostatic graphite were used to solve this problem.

Methods of statistical data were used for construction of the averaged dependence on basic mechanical properties of some of the most common examples of foreign fine-grained graphite brands and isostatic graphite production trends.

\section{Research results}

6.1. Analysis of the current state of isostatic graphite production technology. It is well-known that isostatic graphite production process begins with the preparation of raw materials, namely, crushing filler that is a coke of different nature and training «matrix - binder» that is usually coal tar pitch [11].

Shale [5, 7], oil [6], pitch coke [1, 8, 9] and coke breeze mixture of different nature are used as a filler [8]. Needle coke is practically not used as relatively high anisometric particles are formed after the crushing process, but this coke allows to obtain high-density material with a low coefficient of thermal expansion (CTE) [1].

There is a one-component technology for isostatic graphite based on pitch mesophase obtained by special heat treatment of pitch coal. Powder of this material is viscous and does not require any binders in structural graphite production. As a result, the products obtained from mesophase pitch powders have high isotropy, physical and mechanical properties [14].
The filler undergoes grinding in order to obtain fractions with an average grain size of $30-150 \mu \mathrm{m}$ for fine grained marks or graphite to $1-30 \mu \mathrm{m}$ for ultra fine brands. As a result of analysis of the products on the basis of the following isostatic graphite companies:

- SGL Carbon (Germany);

- Mersen (France);

- Toyo Tanso (Japan);

- GrafTech (USA);

- JSC «NIIgrafit» (Russia).

It was found out that fine grained isostatic graphite with average grain size of $10-20 \mu \mathrm{m}$ is currently most in demand on the international market. It is also important to note that ultra fine grinding carbon fillers with a particle size of about $1 \mu \mathrm{m}$ are achieved by mechanical energy of $15 \mathrm{~kJ} / \mathrm{g}$. With the particle size decrease from $30 \mu \mathrm{m}$ to $1 \mu \mathrm{m}$, grinding energy goes up by more than three orders of magnitude [1]. It also leads to lower perfection degree of the crystal structure of carbon fillers. The material destruction to a particle size less than $1 \mu \mathrm{m}$ reduces the ability of its graphitization [15]. This fact shows the impossibility to use this material as filler for artificial graphite production, at least if there is a necessity to obtain material with high thermal and electrical conductivity.

It is also important to choose a size distribution of the filler so that during one work cycle it would be possible to get graphite blanks with the apparent density of $1700 \mathrm{~kg} / \mathrm{m}^{3}$. Such optimization in some cases makes it possible to increase the apparent graphite density obtained with $150 \mathrm{~kg} / \mathrm{m}^{3}$ and receive finished products from fine-grained graphite without additional technological cycles «impregnation - firing» [1]

It was found out that the packing density of the filler is defined by the size of the largest and smallest particle sizes. The bigger the difference the higher packing density is achieved. Fig. 1 shows the dependence of the maximum volume fraction of the filler on the ratio of particle size limits $\delta_{\min } / \delta_{\max }$ in polydisperse filler. Anisometry of the particles in the circumstances is a negative factor that reduces packing density [1]. Fig. 2 shows the results of theoretical calculations of determination the optimum filler size distribution for $\delta_{\max }=100 \mu \mathrm{m}$ [16].

For the systems, providing maximum packing density, the amount of binder is given by the free volume, that is the value $\left(100-P_{f}\right)$, as shown in Fig. 1.

For example, coal tar pitch preparation can be made using controlled heat treatment up to the temperature of $630^{\circ} \mathrm{C}$ [8] or by adding up to $1.5 \%$ of fine-dispersed carbon special supplements while mixing and heating the mixture:

- complex phenols and phenyl phosphates [5];

- fullerenes and fullerites [7];

- nanodisperse carbon [7, 9];

- expanded natural graphite, etc. [9].

Such preparations allow to increase the physical, chemical and technological characteristics of the coke and pitch mixture that is highly important at different stages of artificial graphite production. It also allows to create a spatial structure, which makes it possible to increase the technological properties of the final product.

After components preparation is completed, they are thoroughly mixed while heating to the temperature which is much higher than the pitch softening temperature. This coke and pitch composition mainly consists by $60-72 \%$ (by mass) of the filler and by $28-40 \%$ (by mass) of the binder material $[1,5,6,9]$. 


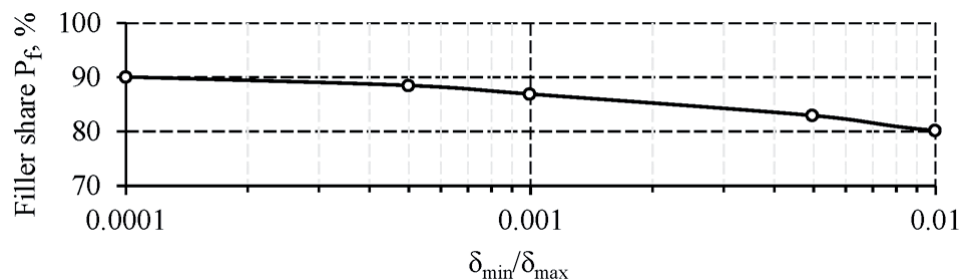

Fig. 1. Dependence of maximum volume particle of the filler on particle size correlation $\delta_{\min } / \delta_{\max }$ in polydisperse fillers [16]

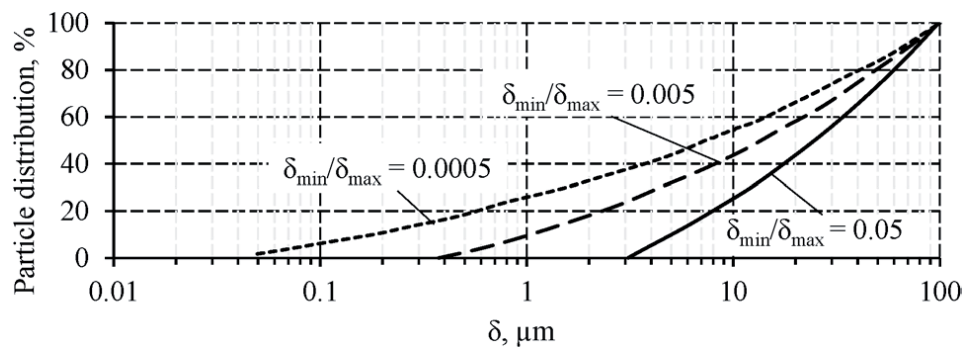

Fig. 2. Theoretical function value of particles division by size providing maximum packing density [16] lowing manufacturers was used to build data dependencies:

- GrafTech Int. (USA) [21];

- SGL Carbon (Germany) [22];

- Mersen (France) [23];

- Toyo Tanso (Japan) [24];

- Ibiden Co. (Japan) [25].

With the grain size drop we can see that fine graphite CTE increases. It is related to the crystals growth leading to the thermal expansion of graphite [16]. In addition, the temperature at the oxidation start in air varies is increased from $400{ }^{\circ} \mathrm{C}$ to $500{ }^{\circ} \mathrm{C}$, which is caused by the decrease of the average pore size $[16,26]$. By adding boron as a modifier, the increase of the temperature at the oxidation start can be achieved in air to $700{ }^{\circ} \mathrm{C}$ and CTE can be reduced below $10^{-6} \mathrm{~K}^{-1}$ [27].

The final stage of isostatic graphite production is a mechanical processing of graphite blanks and, if necessary, a thermal treatment can be also performed.

Then the resulting mass is cooled to ambient temperature, crushed, milled and then we eventually get the moulding powder of the required fraction.

Isostatic pressing process takes place at normal temperature in isostatic presses using liquid substance which on all sides evenly compresses the moulding powder prepared by pressure value $40-200 \mathrm{MPa}[5,8,9,17,18]$. This process allows to obtain a graphite material with higher bulk density, low porosity and high hardness.

After that pressed blanks undergo heat treatment, firing at the temperature of $800-1300{ }^{\circ} \mathrm{C}$ and graphitization at the temperatures up to $3000{ }^{\circ} \mathrm{C}$. After the firing process the blanks are impregnated with the binder if necessary and then stage of firing repeats again. In the process of heat treatment, the blanks decrease in volume and become more condensed [19]. The value of volumetric shrinkage depends on the basic way and the choice of filler content in the volatile and may reach up to $50 \%$ of the original volume of the pressed material [17-20].

As a result of the above actions, fine particle isostatic graphite is obtained, which is characterized by the following physical properties (according to s. c.) [4]:

- specific electrical resistance $-10-15 \mu \Omega \cdot \mathrm{m}$;

- thermal conductivity - 70-140 W/(m.K);

- CTE (up to $200^{\circ} \mathrm{C}$ ) $-3 \cdot 10^{-6}-5 \cdot 10^{-6} \mathrm{~K}^{-1}$, den-

sity $-1.7-1.9 \mathrm{~g} / \mathrm{cm}^{3}$.

The strength of isostatic graphite depends on the average grain size [1]. Fig. 3 shows the dependence of modulus of elasticity and strength characteristics of various types of structural graphite on the average grain size of the filler adduced to the material values with zero porosity. The information available in public access regarding the properties of 100 most popular brands of foreign examples of highly grained graphite of the fol-
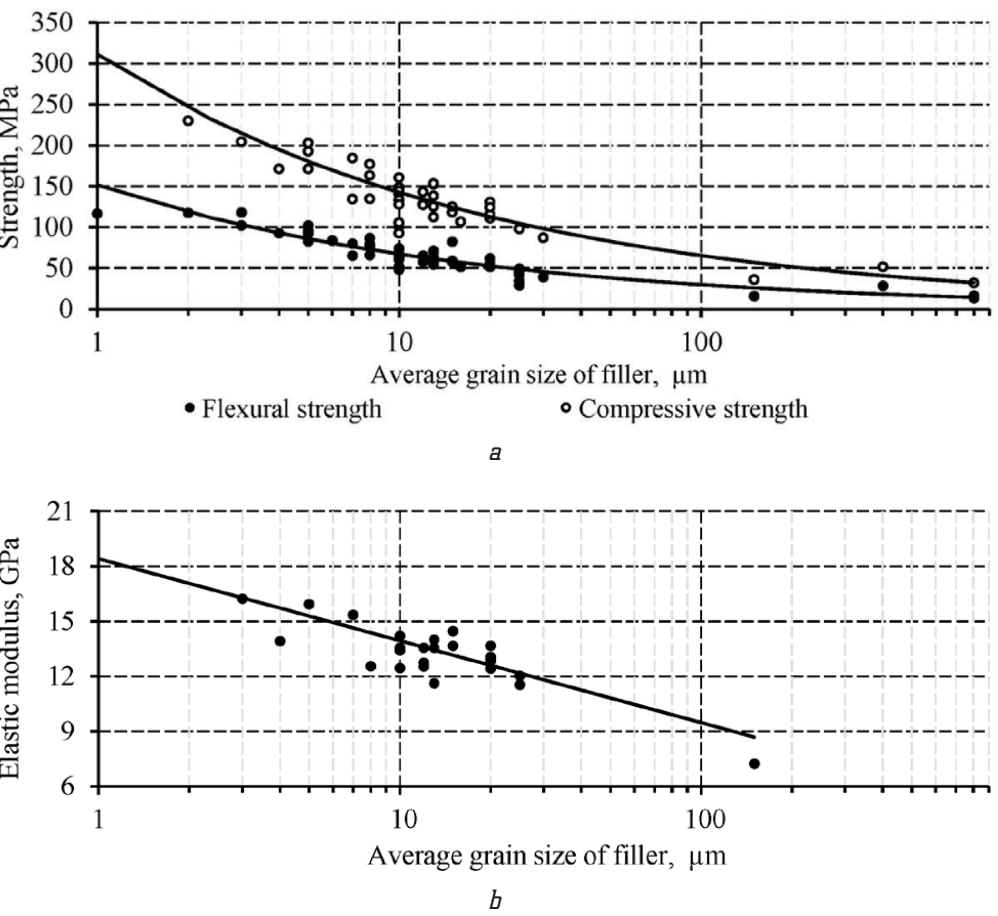

Fig. 3. Dependence on average size filler grains: a - strength boarder; $b$ - elastic modulus for various artificial graphite brands

6.2. Prospects of world isostatic graphite material production. Nowadays the leading manufacturers of the artificial construction graphite are [28]:

- GrafTech Int. (USA);

- Graphite India (India);

- HEG (India);

- JSC Energoprom Management (Russia);

- Nippon Carbon Co. (Japan);

- SEC Carbon (Japan);

- SGL Carbon Group (Germany);

- Showa Denko Carbon Inc. (USA);

- Ibiden Co. (Japan);

- Mersen Group (France); 
- Poco Graphite Inc. (USA);

- Toyo Tanso Co. (Japan);

- Schunk Group (Germany).

The development of photovoltaic industry, growth in production of semiconductors, improvement of EDM technology increase the demand for isostatic graphite [3, 12, 13]. It also makes the above companies expand the range of products and improve production technology. The current world production of isostatic graphite is about $120 \mathrm{kt} / \mathrm{a}$ and still continues to grow [3].

As a result of analysis of available data, it was found out that in the next few years the significant increase in world production of isostatic graphite is expected over $5 \%$ annually (Fig. 4). Under these circumstances, the greatest production growth is expected in China (Fig. 5), which is over a quarter of the total world isostatic graphite production [3].

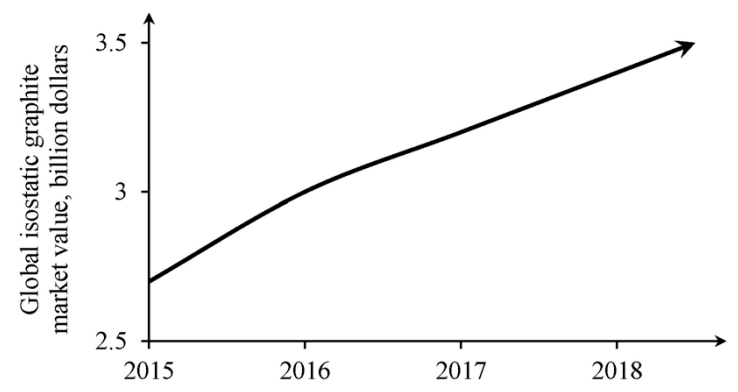

Fig. 4. Global isostatic graphite production tendency [3]

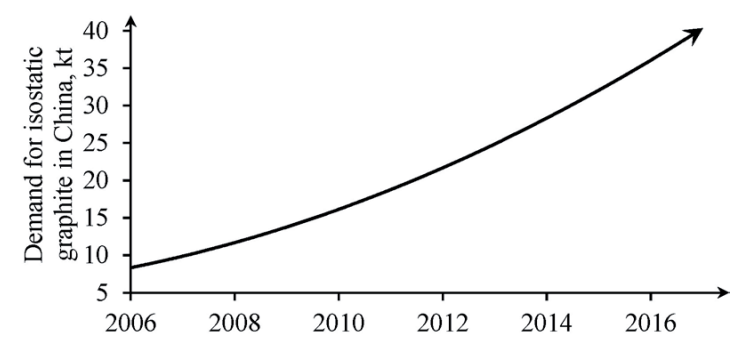

Fig. 5. Isostatic graphite production tendency in China [3]

This growing tendency of graphite material production contributes to the development of new isostatic graphite production technologies in Ukraine. As a result, it will enable Ukrainian producers to compete with foreign companies in the production of fine-dispersed graphite brands.

\section{SWOT analysis of research results}

Strengths. The strength of this study is the proof of principle opportunities and prospects of isostatic graphite production on Ukrainian market of graphite products. Experience of Ukrainian manufacturers in carbon and graphite products allows to develop quickly and introduce new technology with the opportunity to compete with global producers.

Weaknesses. The weak point of isostatic graphite manufacturing process is a complicated phased manufacturing technology, which requires:

- significant human and energy resources;

- use of specialized powerful crush and bale equipment;

- development of rational treatment modes etc.
As a result, this affects the high price of the final product.

Opportunities. Opportunities for further research related to improve of the process technology in isostatic graphite production:

- development of equipment and rational modes of grinding, mixing and pressing of coke and pitch compositions using available Ukrainian brands of coke and pitch;

- experimental studies of full-stage heat treatment of pressed billets to reduce the specific consumption of electricity to produce the finished product.

Threats. The lack of fully developed competitive production technologies of isostatic graphite threatens its future development in Ukraine. In addition, the introduction of industrial production of solar photovoltaic cells based on graphene [29, 30] may lead to significant overall slowdown in world isostatic graphite production.

\section{Conclusions}

1. It was established that the scheme for artificial isostatic graphite includes:

- crushing and grinding filler;

- mixing it with a binder and getting coke and pitch composition;

- coke and pitch composition grinding into moulding powder;

- forming blanks by isostatic pressing;

- burning in the recovery or neutral medium to the temperature of $800-1300{ }^{\circ} \mathrm{C}$;

- graphitization at the temperature of $2500-3000{ }^{\circ} \mathrm{C}$.

2. The features of isostatic graphite production technologies that promote energy efficiency and make it possible to improve the physical and mechanical characteristics of the starting material. These features include:

- choice of components and their composition for coke and pitch mixture;

- adding special modifiers;

- optimization of particle size distribution of the filler;

- setting the pressure for pressing moulding powder;

- choice of blanks thermal processing modes etc.

3. Further growth in global demand is predicted for isostatic graphite materials and products based on it, which is more than $5 \%$ of the annual global volume of production. The leading country in isostatic graphite production is China.

\section{References}

1. Kostikov, V. I. Novye vysokoprochnye uglerodnye materialy dlia vysokih tehnologii [Text] / V. I. Kostikov, V. M. Samoilov, N. Yu. Beilina, B. G. Ostronov // Rossiiskii himicheskii zhurnal. - 2004. - Vol. XLVIII, № 5. - P. 64-75.

2. Castings of metallic alloys with improved surface quality, structural integrity and mechanical properties fabricated in finegrained isotropic graphite molds under vacuum [Text]: Patent US 6799626 B2, Int. Cl.7 B22C 9/00, B22C 3/00/ Ranjan R., Donald W. S.; assignee: Santoku America, Inc. Appl. No. 10/143,920; filed 14.03.2002; publ. 05.10.2004. - 36 p.

3. Global Isostatic Graphite Market 2015 Industry Trends, Analysis \& Forecast to 2020 [Text]. - Florida: QY Research, 2015. - 153 p.

4. Inagaki, M. Advanced Materials Science and Engineering of Carbon [Text] / M. Inagaki, F. Kang, M. Toyoda, H. Konno. Oxford: Butterworth-Heinemann, 2014. - 440 p. doi:10.1016/ c2012-0-03601-0 
5. Sposob polucheniia grafitirovannogo materiala [Text]: Patent RU 2252190 C1, MPK7 C 01 B 31/02, S 04 B 35/52/ Eliseev Yu. S., Poklad V. A., Shutov A. N., Vasilev Yu. N., Sankin A. E.; assignee: JSC «GTERPC «SALUT». Appl. No. 2004107239/15; filed 12.03.2004; publ. 20.05.2005, Bull. № 14. - 6 p.

6. Sposob polucheniia vysokoplotnyh melkozernistyh uglegrafitovyh materialov [Text]: Patent RU 2256610 C2, MPK7 C 01 B 31/04, S 04 B 35/52 / Sviridov A. A., Seleznev A. N., Podkopaev S. A., Gnedin Yu. F., Sherriuble V. G., Sherriuble V. G.; assignee: «Chelyabinsk Electrode Plant» OJSC. - Appl. No. 2003116383/15 filed 04.06.2003; publ. 27.02.2005, Bull. № 20. -5 p

7. Nanostrukturirovannyi kamennougol'nyi pek I sposob ego polucheniia [Text]: Patent RU 2394870 C1, MPK (2006.01) C10C 3/10, B82B 1/00 / Beilina N. Yu., Lipkina N. V., Petrov A. V., Roshchina A. A., Starichenko N. S.; assignee: State Research Institute of Structural Materials Based on Graphite «Nigrafit». Appl. No. 2008148549/04; filed 10.12.2008; publ. 20.07.2010, Bull. № 20. -8 p

8. Sposob izgotovleniia zagotovok iz melkozernistogo grafita [Text] Patent RU 2488554 C2, MPK (2006.01) C01B 31/04, S 04 B 35/52 / Klimenko A. A., Morozov S. M., Filippova L. I. Appl. No. 2011142450/05; filed 21.10.2011; publ. 27.07.2013, Bull. № 21. -8 p.

9. Sposob polucheniia zagotovok iz melkozernistogo grafita [Text] Patent RU 2493098 C1, MPK (2006.01) C01B 31/04, B82B 3/00, (2011.01) B82Y 30/00 / Lavrenov A. A., Fokin V. P.; assignee: LLC «Doncarb Graphite». - Appl. No. 2012100051/05; filed 11.01.2012; publ. 20.09.2013, Bull. № 26. - 11 p.

10. Nonishneva, N. P. Issledovaniia v oblasti razrabotki otechestvennoi tehnologii polucheniia izostaticheskogo grafita [Text]: Proceedings of the 67th Scientific Conference / N. P. Nonishneva, A. V. Frolov // Nauka YuUrGU. Sektsii estestvennyh nauk. Cheliabinsk: Izdatelskii tsentr YuUrGU, 2015. - P. 364-368

11. Asao, O. High density isotropic graphites and glassy carbons. Japanese situation: production, properties and applicaitions [Text] / O. Asao; ed. By H. Marsh, E. A. Heintz, F. Rodriques-Reinoso. Alicante: Universidad de Alicante. Secretariado de Publicationes, 1997. $-564 \mathrm{p}$

12. Randall, T. The world nears peak fossil fuels for electricity [Electronic resource] / T. Randall. - 13.06.2016. - Available at: \www/ URL: https://www.bloomberg.com/news/articles/2016-06-13/weve-almost-reached-peak-fossil-fuels-for-electricity. - 01.02.2017. Title from the screen.

13. Freik, D. M. Photovoltaic Converters of Solar Radiation Achievements, Current Status and Trends (Review) [Text] D. M. Freik, V. M. Chobanyuk, M. O. Galuschak, O. S. Krunutcky, G. D. Mateik // Physics and Chemistry of Solid State. - 2012. - Vol. 13, № 1. - P. 7-20.

14. Hoffmann, W. R. Sintering of powders of polyaromatic mesophase to high-strength isotropic carbons - I. Influence of the raw material and sintering conditions on the properties of the carbon materials [Text] / W. R. Hoffmann, K. J. Hüttinger // Carbon. - 1994. - Vol. 32, № 6. - P. 1087-1103. doi:10.1016/0008-6223(94)90218-6

15. Samoilov, V. M. Vliianie sverhtonkogo izmel'cheniia na kristallicheskuiu strukturu i grafitiruemost' tonkodispersnyh uglerodnyh napolnitelei [Text] / V. M. Samoilov, A. N. Streletskii // Himiia tverdogo topliva. - 2004. - № 2. - P. 53-59.

16. Samoilov, V. M. Poluchenie tonkodispersnyh uglerodnyh napolnitelei I razrabotka tehnologii proizvodstva tonkozernistyh grafitov na ih osnove [Text]: The author's abstract of the thesis of the Doctor of Technical Sciences: 05.17.11 / V. M. Samoilov; State Research Institute of Structural Materials Based on Graphite «Nigrafit». - Moscow, 2006. - 56 p.

17. Timoshchuk, E. V. Vliianie dlitel'nosti sovmestnogo vibroizmel'cheniia I davleniia pressovaniia na plotnosti I usadki zagotovok grafita [Text] / E. V. Timoshchuk, V. M. Samoilov, E. I. Timoshchuk, V. K. Smirnov // Himiia tverdogo topliva. 2011. - № 1. - P. 60-64.
18. Chard, W. Advanced High Pressure Graphite Processing Technology [Text] / W. Chard, M. Conavway, O. Niesz // Petroleum Derived Carbons. - 1979. - Vol. 21. - P. 155-171. Doi:10.1021/bk-1976-0021.ch014

19. Timoshchuk, E. I. Determination of the Particle Size of Fine Powders of the Artificial Graphite by Laser Diffraction [Text] / E. I. Timoshchuk, V. M. Samoilov, A. Ya. Lyapunov, Yu. M. Balaklienko, A. B. Borunova // Industrial laboratory. Materials diagnostics. - 2012. - Vol. 78, № 11. - P. 25-28.

20. Samoilov, V. M. Udel'naia poverhnost', razmery i forma chastits tonkodispersnyh uglerodnyh napolnitelei [Text] / V. M. Samoilov // Neorganicheskie materialy. - 2010. - Vol. 46, № 8. P. $913-918$.

21. Ucar isostatic molded graphite [Electronic resource] // MatWeb. Available at: \www/URL: http://www.matweb.com/search/ QuickText.aspx?SearchText=UCAR\%20Isostatic\%20Molded\%20 Graphite. - 01.02.2017. - Title from the screen.

22. Technical Data Sheets: SIGRAFINE Isostatic Graphite [Electronic resource] // SGL Group - The Carbon Company - Available at: \www/URL: https://www.sglgroup.com/cms/international/ infokorb/Downloadcenter/products/fgg/technical-data-sheets/ iso/index.html. - 01.02.2017. - Title from the screen.

23. Main graphite grades [Electronic resource] // MERSEN. Available at: \www/URL: https://www.mersen.com/fileadmin/user upload/pdf/ht/19-graphite-grades-mersen.pdf. - 01.02.2017. Title from the screen.

24. Special Graphite (Isostatic Graphite) [Electronic resource] // TOYO TANSO. - Available at: \www/URL: http://www.toyotanso.com/Products/Special graphite/data.html. - 01.02.2017. Title from the screen.

25. Property Data [Electronic resource] // IBIDEN Fine Graphite Material. - Available at: \www/URL: https://www.fgm.ibiden. co.jp/multilanguage/english/list.html. - 01.02.2017. - Title from the screen.

26. Butyrin, G. M. Plotnost', poristaia struktura i gazodinamicheskie harakteristiki tonkozernistyh grafitov (obzor) [Text] / G. M. Butyrin // Himiia tverdogo topliva. - 2015. - № 5. P. $40-53$

27. Tracy, L. A. The characterization of highly crystalline, isotropic graphite [Electronic resource] / L. A. Tracy, J. M. Doug // Carbon 2007 Conference, 15-20 July 2007, Seattle, Washington, USA. - Available at: \www/URL: http://acs.omnibooksonline. com/data/papers/2007_D021.pdf

28. Lgalov, V. V. Izuchenie ekspluatatsionnoi stoikosti detalei iz iskusstvennogo grafita pri izgotovlenii metallostekliannyh soedinenii [Text]: Proceedings of the V All-Russian Scientific Conference with International Participation / V. V. Lgalov, A. M. Tokarev // Zhiznennyi tsikl konstruktsionnyh materialov. - Irkutsk, 2015. - P. 56-64.

29. Dodoo-Arhin, D. Inkjet-printed rapheme electrodes for dyesensitized solar cells [Text] / D. Dodoo-Arhin, R. C. T. Howe, G. Hu, Y. Zhang, P. Hiralal, A. Bello et al. // Carbon. 2016. - Vol. 105. - P. 33-41. Doi:10.1016/j.carbon.2016.04.012

30. Liu, Z. Ultrathin and flexible perovskite solar cells with rapheme transparent electrodes [Text] / Z. Liu, P. You, C. Xie, G. Tang, F. Yan // Nano Energy. - 2016. - Vol. 28. - P. 151-157. Doi:10.1016/j.nanoen.2016.08.038

\section{ИССЛЕДОВАНИЕ СОВРЕМЕННОГО СОСТОЯНИЯ ТЕХНОЛОГИИ ПРОИЗВОДСТВА ИЗОСТАТИЧЕСКОГО ГРАФИТА}

Проанализированы основные этапы современной технологии производства высокодисперсного изостатического графита. Установлены особенности и возможные направления ее совершенствования на предприятиях Украины. Рассмотрены основные факторы, которые определяют спрос на изостатический графитовый материал. Спрогнозирован дальнейший рост более чем на 5 \% ежегодного объема производства изостатического графита на мировом рынке, особенно в странах Восточной Азии. 
ключевые слова: изостатический графит, изостатическое прессование, фотогальваническая промышленность, термостойкий материал, коксопековая композиция.

Karvatskii Anton, Doctor of Technical Sciences, Professor, Department of Chemical, Polymer and Silicate Engineering, National Technical University of Ukraine «Igor Sikorsky Kyiv Polytechnic Institute»,Ukraine, e-mail: anton@rst.kpi.ua, ORCID: http://orcid.org/ 0000-0003-2421-4700

Leleka Serhii, PhD, Researcher, Scientific Research Center «ResourceSaving Technologies», National Technical University of Ukraine «Igor
Sikorsky Kyiv Polytechnic Institute»,Ukraine, e-mail: sleleka@rst.kpi.ua, ORCID: http://orcid.org/0000-0002-4372-9454

Pedchenko Anatolii, Research Fellow, Scientific Research Center «Resource-Saving Technologies», National Technical University of Ukraine «Igor Sikorsky Kyiv Polytechnic Institute», Ukraine, e-mail: anatolek@rst.kpi.ua, ORCID: http://orcid.org/0000-00015065-5003

Lazarev Taras, PhD, Researcher, Scientific Research Center «Resource-Saving Technologies», National Technical University of Ukraine «Igor Sikorsky Kyiv Polytechnic Institute», Ukraine, e-mail: t_lazarev@rst.kpi.ua,ORCID: http://orcid.org/0000-0001-8260-1683

\section{Berbova-Bushura 0. EFFECT DF SURFACE ROLING DN MECHANICAL PROPERTIES OF Ti-AI SYSTEM ALLOY}

Наведено результати обробки поверхні інтерметалідного сплаву Ti-Al методом прокатки роликами. Прокатку роликами здійснювали при зусиллі 350 Н. Випробування на втому проводились при кімнатній температурі при частоті 60 Ги. Встановлено, що після прокатки поверхні роликами втомна міщність сплаву Ti-45Al-5Nb (ат. \%) підвищилась на 4\%, з 675 до 700 МПа. Показано, що поверхнева прокатка зменшує шорсткість поверхні.

Ключові слова: прокатка поверхні роликами, інтерметалідні сплави, сплави системи $T i-A l$, втомні тріщини.

\section{Introduction}

Development of aviation technology, especially turbine construction, has put forward ever-increasing demands on structural materials. Therefore, development of new alloys that can work at elevated temperatures, and search for new combinations of elements that improve heat resistance and high-temperature strength, still attracts the attention of researchers.

Today, one of the most important trends in the development of new metal materials with a high level of mechanical properties at temperatures of $600-800^{\circ} \mathrm{C}$ is the creation of $\mathrm{Ti}-\mathrm{Al}$ ( $\gamma$-TiAl-based alloys) alloys. Interest in this group of materials is based on a unique combination:

- high melting point $\left(1460^{\circ} \mathrm{C}\right)$;

- low density $\left(3.8-4.0 \mathrm{~g} / \mathrm{cm}^{3}\right)$;

- high heat resistance and creep resistance at elevated temperatures;

- high resistance to oxidation.

The specific modulus of elasticity of these alloys is higher than that of titanium and nickel by $50-70 \%$, and this difference remains at elevated temperatures. According to the specific strength of $\gamma$-TiAl alloys in the temperature range $t=600-850^{\circ} \mathrm{C}$, depending on the structural state, can exceed all existing structural materials [1-4].

\section{The object of research and its technological audit}

The object of research is the surface roller burnishing, since for intermetallic alloys of the $\mathrm{Ti}-\mathrm{Al}$ system, the ef- fect of this hardening method on mechanical properties has not been fully studied so far.

Surface roller burnishing is a method of surface treatment of a material, in which the following effects are possible [5-7]:

- Reduction of surface roughness;

- Occurrence of residual stresses of the first kind;

- Increase in microhardness.

A schematic diagram of the surface roller burnishing is shown in Fig. 1 [8].

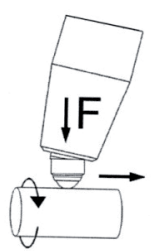

Fig. 1. Schematic diagram of the surface roller burnishing $(F-$ rolling force, $\mathrm{N})$

In the case of this surface treatment, cold hardening, polishing and the occurrence of compressive stresses in the upper layer occur simultaneously. Together, these three physical effects increase fatigue resistance and reduce or completely prevent the formation of cracks in stress corrosion.

When rolling the surface, the rollers are pressed against the surface of the processed material, which leads to plastic deformation in the surface zone. As a result of deformation, the structure of the surface layers of the material 